\title{
GLOBAL REVIEW OF STUDIES ON TRAFFIC POLICE WITH SPECIAL FOCUS ON ENVIRONMENTAL HEALTH EFFECTS
}

\author{
RAJAN R. PATIL, SATISH KUMAR CHETLAPALLY, and MAPILLIRAJU BAGAVANDAS \\ SRM University, Chennai, India \\ School of Public Health
}

\begin{abstract}
Since occupation is a major determinant of health, traffic police personnel face multiple occupational hazards. They are continuously exposed to vehicular emissions and work in a noisy and polluted environment. The objective of the present review is to explore the impact of occupational health hazards on the health of traffic police personnel. Published research papers on traffic police reporting occupational health issues were accessed and reviewed. Attempts were made to access papers that reported negative associations in order to present a balanced review. The majority of the studies have reported a decrease in the lung function and increased respiratory morbidity. The research on the cytogenetic abnormalities or genotoxic effect of vehicular emissions arising due to long-term exposure to benzene and other polyaromatic hydrocarbons has provided conflicting results, since more or less equal numbers of studies have given evidence for and against the causal association. There is a vast accumulation of epidemiological evidence on the casual association between vehicular pollution and its carcinogenic effect. Multiple studies have concluded that traffic police are highly stressed. A number of occupational factors have been attributed to stress among traffic police. Occupational health studies help us to understand the effects of vehicular pollution and its adverse influence on workers. They also provide opportunity for defined exposures measurements and precise risk assessment. The findings from these studies are easily generalizable and can help us understand the impact of air pollution on the general population.
\end{abstract}

Key words:

Traffic police, Occupational health, Vehicular pollution, Health effects

\section{INTRODUCTION}

Air pollution is the major public health problem and vehicular exhaust fumes are the principle source of air pollution in urban areas. A European assessment that suggested air pollution accounts for $6 \%$ of all mortality and $50 \%$ of mortality due to air pollution is accounted for by vehicular pollution [1]. The hazardous traffic fumes contain a variety of pollutants such as particulate matter (PM), carbon monoxide $(\mathrm{CO})$, carbon dioxide $\left(\mathrm{CO}_{2}\right)$, nitrogen dioxide $\left(\mathrm{NO}_{2}\right)$, sulfur dioxide $\left(\mathrm{SO}_{2}\right)$, ozone, etc., all of which can cause respiratory problems and other systemic diseases including cancer $[2,3]$. The respiratory effect due to exposure to vehicular fumes could be both allergic and nonallergic in nature. In addition, vehicular fumes also contain dangerous polyaromatic hydrocarbons like benzene, toluene, xylene which are classified as potentially carcinogenic and genotoxic. PAH are of particular concern because their concentrations in the urban air are 10-30 times higher than rural air concentration [4].

Since occupation is a major determinant of health, traffic police personnel face multiple occupational hazards. 
They are continuously exposed to vehicular emissions, work in noisy and polluted environment. Standing for long hours in a static position makes them vulnerable to ergonomic problems. Managing high volumes of traffic density results in physical and mental fatigue among traffic policemen making them susceptible to physical and mental stress. Both physical and mental health manifestations get accentuated with the increasing length of service [5]. Outdoor occupations in general are hazardous in nature due to prolonged periods of exposure to high concentrations of vehicular pollution putting the employees at increased risk of respiratory and cardiovascular diseases [6].

Traffic police personnel are at the highest risk for the adverse health effect of air pollution, compared to the general population. Occupational studies on traffic police personnel help us to understand the effects of vehicular pollution and its specific adverse effect due to the opportunity for defined exposures measurements [7]. Another very important advantage of studying the impact of vehicular pollution on traffic police is that it helps in quantification of environmental exposures and risk characterization of the health outcome. The objective of the present review is to understand occupational health hazards posed by vehicular pollution and their influence on traffic police personnel. Accordingly, an attempt has been made to access studies conducted on traffic police personnel across the globe and review them to understand the adverse health outcome and its manifestations.

\section{Pulmonary studies}

The majority of studies on traffic personnel investigated the effect of vehicular pollution on the respiratory morbidity and the spirometric values correlated with it, vitalgraph [8] or peak flow meter [5,9]. Most of the studies showed a decreased lung function with a significant reduction in the forced expiratory volume in $1 \mathrm{~s}$ $\left(\mathrm{FEV}_{1}\right)$, forced vital capacity (FVC), vital capacity (VC), peak expiratory flow rate (PEFR), compared to the control subjects. Cases of lung disorders were also observed $[4,10-18]$. The height of the police personnel and years of duty were strong predictors of the pulmonary function in addition to age.

In fact, deterioration of the lung function showed a strong association with the length of service in traffic police [5]. Traffic police exhibited higher respiratory signs and symptoms such as cough, phlegm and rhinitis. A lower lung function was associated with non-use of protective masks among traffic policemen [17,19]. Some studies have looked at the effect of air pollution on vascular inflammatory reactions in traffic policemen [20]. The prevalence of nonspecific respiratory disease (NSRD) showed an association with a higher concentration of particulate matter in the air [21].

\section{Pulmonary biomarkers}

Many investigators have tried to identify biomarkers for chronic effects of vehicular pollution and its respiratory effect on traffic police [22]. Attempts have been made to identify potential biomarkers from 2 pulmonary secreted serum pneumo-proteins, namely Clara cell protein (CC16) and surfactant-associated protein-A (SP-A). It has been proposed that $\mathrm{CC} 16$ could be useful in the detection of chronic effects of vehicular pollution in exposed traffic police. Dust cells and siderocytes detected in induced sputum have been used as a marker of cellular changes and inflammatory infiltrate among the traffic policemen [23]. Exposure to vehicular pollution has been shown to enhance oxidative stress, bring down the levels of antioxidants and nitric oxide. This disturbance in the oxidant/ antioxidant system makes the lungs vulnerable to injury among the traffic police [24].

\section{Negative pulmonary studies}

While the adverse effects of air pollution on the respiratory system may seem to be obvious, interestingly, there 
were many studies that did not show any association between the decline in the lung function when objectively evaluated with spirometers [25,26]. Some studies could not find any difference in respiratory symptoms and allergic sensitization among traffic policemen, compared to the control group [27]. Traffic police showed a higher concentration of $\mathrm{CO}$ in their exhaled air, however, the investigators did not find any clinical manifestations of $\mathrm{CO}$ poisoning [28].

\section{Immunological studies}

Traffic police exposed to vehicular pollution and continued inhalation of traffic exhaust fumes may develop airways inflammation demonstrated by an increased neutrophil cell count in the induced sputum [29]. Traffic police have shown elevated levels of inflammatory markers called high-sensitivity C-reactive protein (hs-CRP) and an increase in the immune makers [30]. Vehicular pollution contributes to the increase in vehicle-related particulate matter air pollution. Colloidal particles from vehicle tires make some of the most important constituents in the urban air particulate matter, and - when inhaled - can cause a respiratory allergy in traffic policemen. The $\operatorname{IgE}$ antibody specific to tire colloidal particle could be tested by a skin-prick test to colloidal-derived antigen [31].

\section{Negative immunological studies}

Allergy-specific respiratory symptoms, and the pulmonary function were investigated among traffic police. Neither respiratory symptoms nor allergic sensitization showed any statistical significance, compared to the control group [27]. Some investigators have used carbon and macrophages filled with hemosiderin as markers of the inflammatory response of the lungs to vehicular pollution among the traffic police. The cytological analysis of sputum did not correlate with smoking and did not show a statistical significance [23].

\section{Cytogenetic studies}

A number of studies among traffic police have investigated genotoxicity resulting from environmental exposure to lead, benzene, polycyclic aromatic hydrocarbons (PAH) and inducing cytogenetic effects. The majority of the studies found increased chromosomal aberration (CA), chromosomal breakage, DNA damage frequencies in lymphocytes, frequencies of micronuclei (MN) and sister-chromatid exchanges (SCEs) in the peripheral blood lymphocytes [32-35]. Attempts have been made to characterize individual exposure to $\mathrm{PAH}$ in the form of different variants of benzene. The researchers looked for the early genetic changes and found significantly increased 32P-postlabeling DNA adducts in WBC obtained from traffic police personnel [36]. Some studies have concentrated on serum p53 protein, which is the factor that determines p53 gene mutation [37].

\section{Negative cytogenetic studies}

Mixed results have been established in studies investigating the cytogenetic effect of exposure to $\mathrm{PAH}$ present in traffic fumes. In fact, a number of studies have failed to detect a chromosomal aberration or DNA damage and to demonstrate the cytogenetic effects or a detectable increase of genetic damage in blood cells [38]. Researchers exploring the genetic effects have also tried to look into cytokinesisblock micronucleus assay and found a weak association between lower micronucleus frequency and the GSTM1 null genotype among traffic police [39]. No correlation was observed between SCE cells and airborne PAH. As a result, the investigators concluded that exposure to urban air pollution does not induce cytogenetic effects among traffic police [40]. Cytognenetic biomonitoring in traffic police workers has also failed to detect any association between micronucleus frequency and vehicular pollution [39]. Analyses of SCE frequencies after 5 years of exposure among traffic police have shown higher values of SCE, but without a statistical significance [41]. Many 
studies have reported statistically significant differences between smokers and non-smokers among the police or control group, instead of a statistical difference between the traffic police and control subjects [42].

\section{Biochemical studies}

Numerous studies have undertaken varied biomonitoring of traffic police officers exposed to vehicular pollution. Researchers have looked at either biomarkers of air pollutants in the blood or the biological outcome due to vehicular pollution in the blood parameters. The investigators have looked at hematological alterations in red blood cells (RBC), mean corpuscular hemoglobin concentrations (MCHC), mean corpuscular hemoglobin $(\mathrm{MCH})$, hematocrit (HCT), mean corpuscular volume (MCV) and reported significantly elevated values [43].

Traffic exhaust fumes have been reported to lead to overexpression of the p53 gene mutation in traffic police officers [37]. The plasma levels of lipid peroxides were very elevated and a reduction in nitric oxide was observed. Apart from that, antioxidants were reduced, but plasma ceruloplasmin, which is an indicator of oxidative stress, did not show any significant change in the examined study participants [24]. The results concerning the carboxyhemoglobin levels suggested that the $\mathrm{COHb} \%$ level did not show a significant correlation with outdoor air quality, on the other hand, it showed an association with the smoking status of traffic police personnel [44]. Some investigators have studied the effect of air pollution on vascular inflammatory reactions in traffic policemen and reported an increase in the Hcy plasma level and a concomitant reduction in nitrite and nitrate serum levels [45].

\section{Negative biochemical studies}

A number of researchers have reported that the $\mathrm{COHb} \%$ level did not show a significant correlation with outdoor air quality, instead they have revealed an association with the smoking status of traffic police personnel [44]. Many reports have stated no association between benzene or other PAH in vehicular pollution and micronucleus frequencies, and found no adverse effect on the hematological values in traffic police personnel [46]. Some investigators, looking at the effect of vehicular pollution on the respiratory system, have tested the study participants for pulmonary secretion serum pneumoproteins, namely Clara cell protein (CC16) and surfactant-associated protein-A (SP-A), as pulmonary biomarkers of the effects of traffic fumes. The serum levels of SP-A did not differ between various groups with a different duration of exposure [22].

\section{Studies on benzene}

Researchers have attempted environmental and biological monitoring of airborne aromatic hydrocarbons such as benzene, toluene, ethylbenzene, xylene and their concentrations. Personal measurements for PAH biomarkers have been carried and benzene was found to be consistently higher among traffic police officers [47]. The geometric mean of benzene in traffic policemen has been reported to be 2 times higher, compared to the controls [48]. Some investigators have reported up to 6-fold higher benzene levels in the examined traffic police. The atmospheric concentrations of the total $\mathrm{PAH}$, benzo(a)pyrene $(\mathrm{BaP})$ and benzo(a)pyrene equivalents $(\mathrm{BaPe})$ were much higher at the road intersections [49]. A significant correlation has been found in traffic police between environmental benzene measured in air and the S-phenylmercapturic acid (S-PMA) as a biomarker [44]. Muconic acid, a marker of benzene exposure, was significantly higher in urban traffic policemen [22].

\section{Negative benzene studies}

Many researchers have reported that vehicular exposure does not cause any significant risk concerning benzene levels among traffic police and the control groups. The findings of a review paper suggest that exposure to low levels of PAH did not show a significant correlation with 
biomarkers of genotoxicity [50]. Studies comparing blood benzene, toluene, ethylbenzene and xylene concentrations did not provide results showing a significant difference between police staff with office-based indoor duty and traffic police with outdoor duty [51]. Some studies have tried to characterize individual exposure to various benzene compounds [52], and have attempted to look at cytogenetic effects, but they have failed to find any cytogenetic effect or any increase in the micronuclei frequency as a result of exposure to vehicular pollution [53].

\section{Lead studies}

Lead is the most frequently tested exposure parameter. Among the traffic police, the blood lead levels were higher than the acceptable limit, which was also demonstrated by the presence of delta-aminolevulinic acid dehydratase, a biomarker of lead exposure [54]. Many traffic police officers showed neurobehavioral symptoms, which were consistent with high blood lead levels [55].

\section{Negative lead studies}

The effect of environmental lead pollution and high blood lead levels have not always yielded convincing positive results. Many studies have failed to detect increased blood lead levels among traffic police, even when the subjects were tested with a sophisticated electro-thermal atomic absorption spectrometer (ET-AAS) [56,57].

The detected blood lead levels among traffic policemen were not associated with the $\mathrm{Hb}$ level, age, or length of service [58]. Numerous investigators have supported the results reporting the lack of a correlation between blood lead levels and duration of employment. In addition, they have failed to find a statistical difference between the mean values for copper among the traffic constables and the controls [59]. Many researchers have reported the lack of cytogenetic effects and chromosomal aberration, as well as the absence of a correlation with the blood lead levels or the duration of employment [33].

\section{Cancer studies}

A number of studies have particularly investigated lung cancer risk associated with exposure to toxic constituents of vehicular pollution. In addition to this, other specific cancer types at different sites like endocrine glands, kidneys, breasts, testicles, melanoma, cervix, colon, bladder, leukemia and lymphomas, and non-Hodgkin's lymphoma have been examined. Some investigators have also focused on the risk associated with exposure to radiofrequencies/microwaves, especially those coming from hand-held radars. The occupational use of hand-held radars that traffic police personnel keep in a close proximity to the testicles has been shown to increase the risk related to testicular cancer $[60,61]$. An association between testicular cancer and a hand-held radar has further been corroborated through a retrospective cohort study among traffic police officers, which showed an increased incidence of testicular cancer and melanoma skin cancer [62]. Another retrospective study has investigated multiple site cancers through past records reporting, all of which have been linked to the use of a police traffic radar [63]. Some researchers have collected data on cancer cases identified through a tumor registry along with death certificates and demonstrated the incidence of cancers with low fatality rates among traffic police [64].

\section{Negative cancer studies}

Many researchers have challenged the link between cancer and radar exposure among traffic police referring to the lack of convincing evidence. They have demonstrated methodological inconsistencies in the published results that have shown an association between high frequency emissions and cancer. Errors have been pointed out especially in the classification of exposure measurements referring to past and current exposures. Another highlighted aspect was the use of biased data and the lack of adjustment for potential confounders in the studies related to traffic police $[65,66]$. 


\section{Standard Mortality Ratio studies}

Multiple retrospective studies have been carried out to investigate the increased Standard Mortality Ratio (SMR). Some have undertaken a secondary data analysis to explore the presence of occupational hazards related to traffic police work and investigated an increase in the probability of death through SMR, compared to the general population and also in comparison to other occupations like fire fighters, clerks, etc. Higher SMR was seen for cancer mortality $[67,68]$. In addition to this, higher proportionate mortality rates (PMR) were noted for arteriosclerotic heart disease (ASHD) for both the working and retired police officers [69].

\section{Endocrinal studies}

Endocrinal studies have been carried out to evaluate the effect of vehicular pollution and psycho-social stressors on the mean plasma concentration of the adrenocorticotropic hormone. The findings showed that the cortisol values were significantly higher in traffic police compared to the controls [70]. Cortisol hormone secretion correlated more with an individual's anxiety in expectation of an impending stressful event than it actually taking place [71]. Some studies have measured the plasma growth hormone $(\mathrm{GH})$ levels and found that it was substantially lower in the exposed traffic policemen [72]. A number of researchers have looked for biomarkers for stress among traffic police. They have demonstrated an increased release of catecholamines and also found that the epinephrine to norepinephrine ratio proved to be a very good marker of stress [71]. Some studies have also looked at the effect of noise pollution on the plasma levels of adrenaline, noradrenaline and dopamine. The investigators have concluded that strong noise load has an impact on the sympatho-adrenomedullary system [73].

\section{Urine analysis studies}

Traffic police studies have included urine analyses as part of the exposure assessment and biomonitoring of PAH exposure. They have also looked for varied biomarkers of vehicular pollution or their consequences, namely phenol, urine hippuric acid, urinary platinum, urinary homovanillic acid, urinary delta-aminolevulenic acid (ALA), and creatinine levels.

Urine trans, trans-muconic acid (ttMA) levels have been found to be a useful monitoring tool for early detection of hazardous benzene exposure that could be used as a biomarker for vehicular pollution exposure [74]. Traffic policemen exposed to heavy traffic showed a higher variation of the urinary homovanillic acid HVA(U) excretion levels in $24 \mathrm{~h}$ [75]. Studies have also estimated the PAH exposure by measuring the urinary 1-hydroxypyrene (1-OHP) levels and reported higher levels in smoking traffic police personnel [76]. The average urine hippuric acid level was demonstrated to be significantly higher in traffic police [77]. Urine phenol levels were found to be significantly elevated among traffic policemen with more than five years of service [78]. The platinum levels were shown to be higher among traffic police as well [79].

\section{Negative urine analysis studies}

The urinary delta-aminolevulenic acid (ALA) tested in traffic police did not show any elevated level compared to the control group [58].

\section{Stress studies}

Multiple studies have concluded that traffic police are highly stressed. A number of factors have been attributed to stress among traffic police, namely inadequate rest periods, lack of communication with the family members, long duty hours, inadequate leave periods, political pressure, excessive number of vehicles on the road, hot weather, noncooperation from the public, lack of coordination among colleagues, seeing too many accidents on the road, problems at home, getting injured, use of force on duty, etc. [80,81].

Some researchers have focused on long-term effects of stress and disease outcomes, cancer, and mortality among 
policemen. The studies have also shown that more than a decade of service in traffic police was a strong predictor for diseases of lymphatic and hematopoietic tissues. Furthermore, it has been demonstrated that traffic personnel who worked for more than four decades of service in traffic police had higher Standard Mortality Ratio (SMR) from all causes, especially arterioscleorotic diseases [68].

\section{OTHER STUDIES}

A relatively small number of studies have focused on the correlation between atmospheric pollution and some possible outcomes: ergonomic impact, damaged oral health, hearing loss, traffic injuries, personal protective equipments (PPEs), reproductive effects in traffic policemen wives, and vascular inflammatory reactions in traffic policemen.

Physical stress among police officers managing traffic is an occupational risk factor for low back pain (LBP). The recurrence of it was associated with the time since the onset, but it was not related to the persistence of LBP [82]. Musculoskeletal problems in traffic police personnel have been reported to be high and they often lead to increased sickness absenteeism. Police personnel driving motorcycles have reported higher shoulder pain [83]. The wives of traffic policemen exposed to vehicular pollution reported an adverse reproductive outcome [84]. The health status and treatment needs assessment showed that a half of the police personnel were suffering from dental caries [85]. The self-reported hearing quality of traffic policemen showed varying levels of auditory and non-auditory health effects caused by noise pollution [86].

The exposure of traffic police officers to particulate matter, carbon monoxide, and benzene has been assessed. The key finding was that airborne concentrations determined by a fixed measurement reported in other studies greatly underestimated the exposure of traffic officers to airborne contaminants [87].

\section{DISCUSSION}

There is enough epidemiological evidence to show that vehicular pollution can cause increased morbidity and mortality. Some health effects may result from short-term exposure, while others are related to long-term exposure. Traffic police have been the natural choice as the subjects for studying adverse health effects from vehicular pollution due to their occupation requiring them to be in the middle of heavy traffic. Although a number of different health effects have been reported, the majority of the studies devoted to traffic police have largely focused on three specific outcomes, namely respiratory morbidity, cytogenic effect and carcinogenic effect [88,89].

The effect of vehicular pollution on the respiratory health has been the primary research question for the majority of the studies looking into health effects of vehicular air pollution. The evidence accumulated in this respect has come from methodologically diverse studies. Most of them have reported a decrease in the lung function and increased respiratory morbidity. Yet, there are many studies that have failed to show any association between vehicular pollution and a decreased lung function. Vehicular traffic contributes a major portion of the air pollution and study results on traffic police can be extrapolated to a larger population, provided that the confounding variables are adjusted for [90,91].

The research on the cryptogenic abnormalities or the genotoxic effect of vehicular emission arising due to longterm exposure to benzene and other PAH has provided conflicting results, since more or less equal numbers of studies have given evidence for and against the causal association. While laboratory-based toxicological experiments on animals have convincingly yielded positive results for the mutagenic effect, the extrapolation of animal laboratory findings to human beings has been controversial $[92,93]$.

There is a vast accumulation of epidemiological evidence on the casual association between vehicular 
pollution and its carcinogenic effect on the exposed individuals. Benzene has been shown to increase the risk of leukemia among children even at very low levels. Based on the available evidence and recommendations of various professional organizations, the World Health Organization (WHO) has declared benzene as the most hazardous pollutant and recommended the zero level as the only safe limit of exposure. Such evidence has led to many public health interventions. Diesel fumes have been classified as a probable human carcinogen by the International Agency for Research on Cancer (IARC). The national Institute of Occupational Health has declared diesel fumes as an occupational carcinogen [94].

The individual health effects among traffic police officers cannot be attributed to specific constituents of the vehicular pollution, since a mixture of multiple constituents act synergistically to induce adverse health outcomes. Any change in the permutation and combination of the constituents of traffic fumes is likely to change the resultant health outcome. A specific pollutant, e.g., particulate matter, will cause different health outcomes depending on its combination with other constituents in the air. Traffic police studies provide the opportunity to study adverse effects of vehicular pollution on different microenvironments with varying levels of the concentration of traffic-related air pollution [95]. Biomarker studies among traffic police personnel are helping to combine the epidemiological and toxicological studies on vehicular pollution exposure. Recent advances in molecular biology have greatly helped in accurate exposure assessment and deeper understanding of the biological basis of the disease causal mechanism. In addition, recent advances in molecular biological studies among traffic police have also helped in identifying high-risk individuals based on their susceptibility profile provided by the presence or absence of certain specific biomarkers [96,97].

\section{REFERENCES}

1. Künzli N, Kaiser R, Medina S, Studnicka M, Chanel O, Filliger P, et al. Public-health impact of outdoor and traffic-related air pollution: A European assessment. Lancet. 2000;356: 795-801, http://dx.doi.org/10.1016/S0140-6736(00)02653-2.

2. Anderson HR, Atkinson RW, Peacock JL, Marston L, Konstantinou K. Meta-analysis of time-series studies and panel studies of particulate matter $(\mathrm{PM})$ and ozone $\left(\mathrm{O}_{3}\right)$ : Report of a WHO task group. Copenhagen: WHO Regional Office for Europe; 2004 [cited 2014 Jan 5]. Available from: http://www. euro.who.int/_data/assets/pdf_file/0004/74731/e82792.pdf.

3. International Agency for Research in Cancer (IARC) Monographs of evaluation of the carcinogen risk of chemicals to humans. Vol 46. Polynuclear aromatic compounds: Diesel and gasoline exhaust and some nitroarenes. Lyon: IARC; 1989 [cited 2014 Jan 5]. Available from: http://monographs.iarc.fr/ ENG/Monographs/vol46/volume46.pdf.

4. Suglia SF, Gryparis A, Schwartz J, Wright RJ. Association between traffic-related black carbon exposure and lung function among urban women. Environ Health Perspect. 2008;116(10):1333-7, http://dx.doi.org/10.1289/ ehp.11223.

5. Satapathy DM, Behera TR, Tripathy RM. Health status of traffic police personnel in Brahmpur City. Indian J Community Med. 2009;34(1):71-2, http://dx.doi.org/10.4103/09700218.45380 .

6. Mills NL, Miller MR, Lucking AJ, Beveridge J, Flint L, Boere AJ, et al. Combustion-derived nanoparticulate induces the adverse vascular effects of diesel exhaust inhalation. Eur Heart J. 2011;32(21):2660-71, http://dx.doi.org/10.1093/eurheartj/ehr195.

7. Brandt HC, Watson WP. Monitoring human occupational and environmental exposures to polycyclic aromatic compounds. Ann Occup Hyg. 2003;47:349-78, http://dx.doi.org/10.1093/ annhyg/meg052.

8. Saenghirunvattana S. Abnormal pulmonary function among traffic policemen in Bangkok. J Med Assoc Thai. 1995;78(12):686-7. 
9. Rahman MA, Badruzzaman ABM, Rahman HM. Assessing the impact of exposure to polluted air on the pulmonary systems of service personnel using a peak flow meter. Aust J Basic Appl Sci. 2010;4(11):5533-49.

10. Karita K, Yano E, Jinsart W, Boudoung D, Tamura K. Respiratory symptoms and pulmonary function among traffic police in Bangkok, Thailand. Arch Environ Health. 2001; 56(5):467-70, http://dx.doi.org/10.1080/00039890109604484.

11. Laumbach RJ, Kipen HM. Respiratory health effects of air pollution: Update on biomass smoke and traffic pollution. J Allergy Clin Immunol. 2012;129(1):3-11, http://dx.doi. org/10.1016/j.jaci.2011.11.021.

12. Singh V, Sharma BB, Yadav R, Meena P. Respiratory morbidity attributed to auto-exhaust pollution in traffic policemen of Jaipur. J Asthma. 2009;46(2):118-21, http://dx.doi. org/10.1080/02770900802448436.

13. Pal P, John RA, Dutta TK, Pal GK. Pulmonary function test in traffic police personnel in Pondicherry. Indian J Physiol Pharmacol. 2010;54(4):329-36.

14. Ingle ST, Pachpande BG, Wagh ND, Patel VS, Attarde SB. Exposure to vehicular pollution and respiratory impairment of traffic policemen in Jalgaon City, India. Ind Health. 2005;43(4):656-62, http://dx.doi.org/10.2486/indhealth.43.656.

15. Thippanna G, Lakhtakia S. Spirometric evaluation of traffic police personnel exposed to automobile pollution in twin cities of hyderabad and secunderabad. Ind J Tub. 1999;46: 129-31.

16. Gupta S, Mittal S, Kumar A, Kamal DS. Respiratory effects of air pollutants among nonsmoking traffic policemen of Patiala, India. Lung India. 2011;28(4):253-7, http://dx.doi. org/10.4103/0970-2113.85685.

17. Wongsurakiat P, Maranetra KN, Nana A, Naruman C, Aksornint M, Chalermsanyakorn T. Respiratory symptoms and pulmonary function of traffic policemen in Thornburi. J Med Assoc Thai. 1999;82:435-43.

18. Ogunsola OJ, Oluwole AF, Asublo OI, Durosinmi MA, Fatusi AO, Ruck W. Environmental impact of vehicular traffic in Nigeria: Health aspects. Sci Total Environ. 1994;146-7: 111-6, http://dx.doi.org/10.1016/0048-9697(94)90226-7.

19. Holguin F. Traffic, outdoor air pollution, and asthma. Immunol Allergy Clin North Am. 2008;28(3):577-88, http://dx.doi. org/10.1016/j.iac.2008.03.008.

20. Zimmerman FH. Cardiovascular disease and risk factors in law enforcement personnel: A comprehensive review. Cardiol Rev. 2012;20(4):159-66, http://dx.doi.org/10.1097/ CRD.0b013e318248d631.

21. Tamura K, Jinsart W, Yano E, Karita K, Boudoung D. Particulate air pollution and chronic respiratory symptoms among traffic policemen in Bangkok. Arch Environ Health. 2003;58:201-7, http://dx.doi.org/10.3200/ AEOH.58.4.201-207.

22. Berthoin K, Broeckaert F, Robin M, Haufroid V, de Burbure $\mathrm{C}$, Bernard A. Serum pneumoproteins and biomarkers of exposure to urban air pollution: A cross-sectional comparison of policemen and foresters. Biomarkers. 2004;9:341-52, http://dx.doi.org/10.1080/13547500400018646.

23. Giovagnoli MR, Alderisio M, Cenci M, Nofroni I, Vecchione A. Carbon and hemosiderin-laden macrophages in sputum of traffic policeman exposed to air pollution. Arch Environ Health. 1999;54:284-90, http://dx.doi. org/10.1080/00039899909602487.

24. Suresh Y, Sailja Devi MM, Manjari V, Das UN. Oxidant stress, antioxidants and nitric oxide in traffic police of Hyderabad, India. Environ Pollut. 2000;109:321-5, http:// dx.doi.org/10.1016/S0269-7491(99)00254-7.

25. Karita K, Yano E, Tamura K, Jinsart W. Effects of working and residential location areas on air pollution related respiratory symptoms in policemen and their wives in Bangkok, Thailand. Eur J Public Health. 2004;14(1):24-6, http:// dx.doi.org/10.1093/eurpub/14.1.24.

26. DeToni A, Larese Filon F, Finotto L. Respiratory diseases in a group of traffic police officers: Results of a 5-year followup. Ital Med Lav Ergon. 2005;27(3):380-2.

27. Proietti L, Mastruzzo C, Palermo F, Vancheri C, Lisitano N, Crimi N. Prevalence of respiratory symptoms, reduction 
in lung function and allergic sensitization in a group of traffic police officers exposed to urban pollution. Med Lav. 2005;96:24-32.

28. Atimtay AT. Urban CO exposure and its health effects on traffic policemen in Ankara. Environ Res. 2000;82(3): 222-30, http://dx.doi.org/10.1006/enrs.1999.4031.

29. Dragonieri S, Musti M, Izzo C, Esposito LM, Foschino Barbaro MP, Resta O, et al. Sputum induced cellularity in a group of traffic policemen. Sci Total Environ. 2006;15;367(1):433-6.

30. Zhao J, Gao Z, Tian Z, Xie Y, Xin F, Jiang R, et al. The biological effects of individual-level $\mathrm{PM}(2.5)$ exposure on systemic immunity and inflammatory response in traffic policemen. Occup Environ Med. 2013;70(6):426-31.

31. Zhang YX, Wei QY, Wang J, Qiao TH, Bai HB, Cai LN. Automobile tyre colloidal particle induced allergic damage of respiratory system in traffic policemen and its allergenicity. Zhonghua Lao Dong Wei Sheng Zhi Ye Bing Za Zhi. 2007;25:346-9.

32. Sreedevi V, Hemaprasad M, Sandhyadevi G, Reddy PP. Induction of sister chromatid exchanges in traffic policemen exposed to vehicular exhaust. Mutat Res. 2006;606:80-4, http://dx.doi.org/10.1016/j.mrgentox.2006.03.004.

33. Anwar WA, Kamal AAM. Cytogenetic effects in a group of traffic policemen in Cairo. Mutat Res. 1988;208:225-31, http://dx.doi.org/10.1016/0165-7992(88)90065-6.

34. Kamboj SS, Sambyal V. Increased chromosomal aberrations in peripheral blood lymphocytes of traffic policemen of Amritsar city. Int J Hum Genet. 2006;6(2):125-31.

35. Zhao X, Niu J, Wang Y, Yan C, Wang X, Wang J. Genotoxicity and chronic health effects of automobile exhaust: A study on the traffic policemen in the city of Lanzhou. Mutat Res. 1998;415(3):185-90, http://dx.doi.org/10.1016/ S1383-5718(98)00066-7.

36. Merlo F, Bolognesi C, Peluso M, Valerio F, Abbondandolo A, Puntoni R. Airborne levels of polycyclic aromatic hydrocarbons: 32P-postlabeling DNA adducts and micronuclei in white blood cells from traffic police workers and urban residents. J Environ Pathol Toxicol Oncol. 1997;16(2-3):157-62.
37. Zhu WC, Chen Q, Chu XW, Luo CL, Wu M, Wang YX, et al. Study on serum $p 53$ protein in cops in Guangzhou city. Zhonghua Liu Xing Bing Xue Za Zhi. 2003;24(10):872-4.

38. Carere A, Andreoli C, Galati R, Leopardi P, Marcon F, Rosati MV, et al. Biomonitoring of exposure to urban air pollutants: Analysis of sister chromatid exchanges and DNA lesions in peripheral lymphocytes of traffic policemen. Mutat Res. 2002;518:215-24, http://dx.doi.org/10.1016/S13835718(02)00108-0.

39. Leopardi P, Zijno A, Marcon F, Conti L, Carere A, Verdina A, et al. Analysis of micronuclei in peripheral blood lymphocytes of traffic wardens: Effects of exposure, metabolic genotypes, and inhibition of excision repair in vitro by ARA-C. Environ Mol Mutagen. 2000;41(3):126-30.

40. Bolognesi C, Gallerani E, Bonatti S, de Ferrarib M, Fontanac V, Valeriodet F, et al. Sister chromatid exchange induction in peripheral blood lymphocytes of traffic police workers. Mutat Res. 1997;394:37-44, http://dx.doi.org/10.1016/ S1383-5718(97)00121-6.

41. Chandrasekaran R, Samy PL, Murthy PB. Increased sister chromatid exchange (SCE) frequencies in lymphocytes from traffic policemen exposed to automobile exhaust pollution. Hum Exp Toxicol. 1996;15:301-4, http://dx.doi. org/10.1177/096032719601500405.

42. Anbazhagan M, Arumugam P, Ramesh A, Santhiya ST. Genetic risk assessment in traffic policemen of Chennai city by sister chromatid exchange analysis. Int J Hum Genet. 2010 [cited 2014 Jan 5];10(4):251-5. Available from: http://www. krepublishers.com/02-Journals/IJHG/IJHG-10-0-000-10-Web/ IJHG-10-4-000-2010-Abst-PDF/IJHG-10-4-251-399-Anbazhagan-M/IJHG-10-4-251-10-399-Anbazhagan-M-Tt.pdf.

43. Tomei G, Ciarrocca M, Capozzella A, Fiaschetti M, Tomao E, Cangemi $\mathrm{C}$, et al. Hemopoietic system in traffic police exposed to urban stressors. Industr Health. 2008;46: 298-301, http://dx.doi.org/10.2486/indhealth.46.298.

44. Bonoa R, Piccionib P, Traversia D, Degana R, Grosac M, Bosellob G, et al. Urban air quality and carboxyhemoglobin levels in a group of traffic policemen. Sci Total 
Environ. 2007;376:109-15, http://dx.doi.org/10.1016/j.scitotenv.2007.01.086.

45. Zawilla N, Suliman D, Mansour N, Ibrahim Y. Air pollution in relation to homocyteine serum level and nitric oxide indicators among traffic policemen in Egypt. Health. 2012;2(1):23-9.

46. Maffei F, Hrelia P, Angelini S, Carbone F, Cantelli Forti G, Barbieri A, et al. Effects of environmental benzene: Micronucleus frequencies and haematological values in traffic police working in an urban area. Mutat Res. 2005;583(1):1-11, http://dx.doi.org/10.1016/j.mrgentox.2005.01.011.

47. Crebelli R, Tomei F, Zijno A, Ghittori S, Imbriani M, Gamberale D, et al. Exposure to benzene in urban workers: Environmental and biological monitoring of traffic police in Rome. Occup Environ Med. 2001;58:165-71, http://dx.doi. org/10.1136/oem.58.3.165.

48. Tomei F, Ghittori S, Imbriani M, Pavanello S, Carere A, Marcon F, et al. Environmental and biological monitoring of traffic wardens in the city of Rome. Occup Med. 2003;51(3): 198-203, http://dx.doi.org/10.1093/occmed/51.3.198.

49. Hu Y, Zhang L, Bai Z, Zhu T, Zhang H, You Y. PAHs exposure assessment for traffic police officers during duty time in Tianjin, China. Epidemiology. 2006;17(6):S459-60, http:// dx.doi.org/10.1097/00001648-200611001-01233.

50. Kyrtopoulos SA, Georgiadis P, Autrup H, Demopoulos NA, Farmer P, Haugen A, et al. Biomarkers of genotoxicity of urban air pollution: Overview and descriptive data from a molecular epidemiology study on populations exposed to moderate to low levels of polycyclic aromatic hydrocarbons (the AULIS projects). Mutat Res. 2001;496:207-28, http:// dx.doi.org/10.1016/S1383-5718(01)00222-4.

51. Fustinoni S, Buratti M, Giampiccolo R, Colombi A. Biological and environmental monitoring of exposure to airborne benzene and other aromatic hydrocarbons in Milan traffic wardens. Toxicol Lett. 1995;77:387-92, http://dx.doi. org/10.1016/0378-4274(95)03322-X.

52. Lioy PJ, Fan Z, Zhang J, Georgopoulos P, Wang SW, Ohman-Strickland P, et al. Personal and ambient exposures to air toxics in Camden, New Jersey. Res Rep Health Eff Inst. 2011;(160):3-127.

53. Georgiadis P, Kyrtopoulos SA. Molecular epidemiological approaches to the study of the genotoxic effects of urban air pollution. Mutat Res. 1999;428(1-2):91-8, http://dx.doi. org/10.1016/S1383-5742(99)00035-6.

54. Farsam H, Salari GH, Nadim A. Absorption of lead in Teheran traffic policemen. Am Ind Hyg Assoc J. 1982;43(5): 373-6, http://dx.doi.org/10.1080/15298668291409884.

55. Ahmed NS, el-Gendy KS, el-Refaie AK, Marzouk SA, Bakry NS, el-Sebae AH, et al. Assessment of lead toxicity in traffic controllers of Alexandria, Egypt, Road Intersections. Arch Environ Health. 1987;42:92-5, http://dx.doi.org/ 10.1080/00039896.1987.9935802.

56. Rahama SM, Khider HE, Mohamed SN, Abuelmaali SA, Elaagip AH. Environmental pollution of lead in traffic air and blood of traffic policemen in Khartoum State, Sudan. East Afr J Public Health. 2011;8(2):138-40.

57. Pala K, Akiş N, Izgi B, Gücer S, Aydin N, Aytekin H, et al. Blood lead levels of traffic policemen in Bursa, Turkey. Int J Hyg Environ Health. 2002;205(5):361-5, http://dx.doi. org/10.1078/1438-4639-00169.

58. Kamal AA, Eldamaty SE, Faris R. Blood lead level of Cairo traffic policemen. Sci Total Environ. 1991;105:165-70, http:/ dx.doi.org/10.1016/0048-9697(91)90339-G.

59. Agha F. Effect of environmental lead pollution on blood lead levels in traffic police constables in Islamabad, Pakistan. J Pak Med Assoc. 2005;55(10):410-3.

60. Finkelstein MM. Cancer incidence among Ontario police officers. Am J Ind Med. 1998;34:157-62, http://dx.doi. org/10.1002/(SICI)1097-0274(199808)34:2\%3C157::AIDAJIM8\%3E3.0.CO;2-U.

61. Moore MA. Traffic air pollution - is it safe to be a traffic policeman or professional driver? Asian Pac J Cancer Prev. 2005;6(2):107-9.

62. Davis RL, Mostofi FK. Cluster of testicular cancer in police officers exposed to hand-held radar. Am J Ind Med. 1993;24: 231-3, http://dx.doi.org/10.1002/ajim.4700240209. 
63. van Netten C, Brands RH, Hoption Cann SA, Spinelli JJ, Sheps SB. Cancer cluster among police detachment personnel. Environ Int. 2003;28(7):567-72, http://dx.doi. org/10.1016/S0160-4120(02)00082-X.

64. Demers PA, Vaughan TL, Checkoway H, Weiss NS, Heyer NJ, Rosenstock L. Cancer identification using a tumor registry versus death certificates in occupational cohort studies in the United States. Am J Epidemiol. 1992;136(10):1232-40.

65. Breckenkamp J, Berg G, Blettner M. Biological effects on human health due to radiofrequency/microwave exposure: A synopsis of cohort studies. Radiat Environ Biophys. 2003;42(3):141-54, http://dx.doi.org/10.1007/s00411003-0203-x.

66. Lotz WG, Rinsky RA, Edwards RD. Occupational exposure of police officers to microwave radiation from traffic radar devices. National Technical Information Service (NTIS) Publication Number PB95-261350 [cited 2014 Jan 4]. Available from: http://www.osha.gov/SLTC/radiofrequencyradiation/fnradpub.html.

67. Violanti JM, Vena JE, Petralia S. Mortality of a police cohort: 1950-1990. Am J Ind Med. 1998;33(4):366, http://dx.doi.org/10.1002/(SICI)1097-0274(199804)33: 4\%3C366::AID-AJIM6\%3E3.0.CO;2-S.

68. Vena JE, Violanti JM, Marshall J, Fiedler RC. Mortality of a municipal worker cohort: 111. police officers. Am J Ind Med. 1986;10:383-97, http://dx.doi.org/10.1002/ ajim. 4700100406 .

69. Feuer E, Rosenman K. Mortality in police and firefighters in New Jersey. Am J Ind Med. 1986;9:517-27.

70. Tomei F, Rosati MV, Baccolo TP, Bernardini A, Ciarrocca M, Tomao E. Plasma concentration of adrenocorticotropic hormone in traffic policemen. J Occup Health. 2003;45:242-7, http://dx.doi.org/10.1539/joh.45.242.

71. Cianfarani F, Valli M. Evaluation of biological stress markers in police officers. Med Law. 1990;18:125-44.

72. Tomei F, Rosati MV, Baccolo TP, Morelli A, Anzelmo V, Ciarrocca M, et al. Occupational exposure to urban pollutants and plasma growth hormone (GH). J Environ Sci
Health A Tox Hazard Subst Environ Eng. 2003;38(6):101724, http://dx.doi.org/10.1081/ESE-120019860.

73. Fruhstorfer B, Pritsch MG, Pritsch MB, Clement HW, Wesemann W. Effects of daytime noise load on the sleepwake cycle and endocrine patterns in man. III. 24 hours secretion of free and sulfate conjugated atecholamines. Int J Neurosci. 1988;43(1-2):53-62, http://dx.doi.org/10. 3109/00207458808985779.

74. Wiwanitkit V, Suwansaksri J, Soogarun S. A note on urine trans, trans-muconic acid level among a sample of thai police: Implication for an ccupational health issue. Yale J Biol Med. 2003;76(3):103-8.

75. Tomei F, Rosati MV, Ciarrocca M, Cherubini E, Baccolo TF, Tomao E. Work exposure to urban pollutants and urinary homovanillic. Acid J Environ Sci Health A Tox Hazard Subst Environ Eng. 2003;38(12):2909-18.

76. Burgaz S, Demircigil GC, Karahalil B, Karakaya AE. Chromosomal damage in peripheral blood lymphocytes of traffic policemen and taxi drivers exposed to urban air pollution Chemosphere. 2002;47(1):57-64, http://dx.doi.org/10.1016/ S0045-6535(01)00185-0.

77. Wiwanitkit V, Suwansaksri J, Soogarun S. High urine hippuric acid level among police working close to traffic in an urban area, Thailand: A preliminary study. Stoch Environ Res Risk Assess. 2008;22:281-3, http://dx.doi.org/10.1007/ s00477-007-0111-8.

78. Soogarun S, Wiwanitkit V, Suwansaksri J. Urine phenol levels among Thai police, implications for occupational health. Southeast Asian J Trop Med Public Health. 2004;35(4): 1034-5.

79. Iavicoli I, Bocca B, Petrucci F, Senofonte O, Carelli G, Alimonti A, et al. Biomonitoring of traffic police officers exposed to airborne platinum. Occup Environ Med. 2004;61:636-9, http://dx.doi.org/10.1136/oem.2003.010744.

80. Pancheri P, Martini A, Tarsitani L, Rosati MV, Biondi M, Tomei F. Assessment of subjective stress in the municipal police force of the city of Rome. Stress Health. 2002;18: 127-32, http://dx.doi.org/10.1002/smi.936. 
81. Chakraborthy T. Job-related stress, causal factors and coping strategies of traffic constables. J Indian Acad Appl Psychol. 2008;34(1):19-28.

82. Burton AK, Tillotson KM, Symonds TL, Burke C, Mathewson T. Occupational risk factors for the first-onset and subsequent course of low back trouble. A study of serving police officers. Spine. 1996;21(22):2612-20, http://dx.doi. org/10.1097/00007632-199611150-00011.

83. Gyi DE, Porter JM. Musculoskeletal problems and driving in police officers. Occup Med (Lond). 1998;48(3):153-60, http://dx.doi.org/10.1093/occmed/48.3.153.

84. Devi VS, Prasad MH, Rao VD, Devi GS, Reddy PP. Reproductive outcome in the wives of traffic policemen exposed to automobile exhaust. J Hum Ecol. 2006;20(2):77-82.

85. Sohi RK, Bansal V. Assessment of oral health status and treatment needs of police personnel of Haryana, India. Internet J Epidemiol. 2010;9(1):20-4.

86. Tripathi SR, Tiwari RR. Self-reported hearing quality of traffic policemen: A questionnaire-based study. Indian J Occup Environ Med. 2006;10:82-4, http://dx.doi.org/10.4103/00195278.27306 .

87. Cattaneo IA, Taronna M, Consonni D, Angius S, Costamagna P, Cavallo DM. Personal exposure of traffic police officers to particulate matter, carbon monoxide, and benzene in the city of Milan. J Occup Environ Hyg. 2010;7:342-51.

88. Sydbom A, Blomberg A, Parnia S, Stenfors N, Sandstorm T, Dahlen SE. Health effects of diesel exhaust emissions. Eur Respir J. 2001;17:733-46, http://dx.doi.org/10.1183/ 09031936.01.17407330.

89. Gotschi T, Heinrich J, Sunyer J, Kunzli N. Long-term effects of ambient air pollution on lung function: A review. Epidemiology. 2008;19:690-701, http://dx.doi.org/10.1097/ EDE.0b013e318181650f.
90. Kelly FJ, Fussell JC. Air pollution and airway disease. Clin Exp Allergy. 2011;41:1059-71, http://dx.doi.org/10.1111/ j.1365-2222.2011.03776.x.

91. Balakrishnan K, Ganguli B, Ghosh S, Sankar S, Thanasekaraan V, Rayudu VN, et al. Short-term effects of air pollution on mortality: Results from a time-series analysis in Chennai, India. Res Rep Health Eff Inst. 2011;157:7-44.

92. Bonassi S, Ugolini D, Kirsch-Volders M, Stromberg U, Vermeulen R, Tucker JD. Human population studies with cytogenetic biomarkers: Review of the literature and future prospectives. Environ Mol Mutagen. 2005;45:258-70, http:// dx.doi.org/10.1002/em.20115.

93. Albertini RJ, Anderson D, Douglas GR, Hagmar L, Hemminki K, Merlo F, et al. IPCS guidelines for the monitoring of genotoxic effects of carcinogens in humans. Mutat Res. 2000;463:111-72, http://dx.doi.org/10.1016/S1383-5742 (00)00049-1.

94. Lewtas J, Gallagher J. Complex mixtures of urban air pollutants: Identification and comparative assessment of mutagenic and tumorigenic chemicals and emission sources. IARC Sci Publ. 1990;104:252-60.

95. Wiwanitkit V. Classification of risk occupation for benzene exposure by urine trans, trans-munconic acid level. Asian Pac J Cancer Prev. 2006;7(1):149-50.

96. Sorensen MAH, Moller P, Hertel O, Jensen SS, Vinzents P, Knudsen LE, et al. Linking exposure to environmental pollutants with biological effects. Mutat Res. 2003;544:255-71, http://dx.doi.org/10.1016/j.mrrev.2003.06.010.

97. HEI Panel on the Health Effects of Traffic-Related Air Pollution. Traffic-Related Air Pollution: A critical review of the literature on emissions, exposure, and health effects. HEI Special Report 17. Boston, MA: Health Effects Institute; 2010.

This work is available in Open Access model and licensed under a Creative Commons Attribution-NonCommercial 3.0 Poland License - http://creativecommons.org/ licenses/by-nc/3.0/pl/deed.en. 